\title{
Clinical Features of Early Multiple Sclerosis
}

\section{I. Čelpačenko* \\ R. Stankevičiūtė* \\ M. Malciūté* \\ R. Balnyte்** \\ ${ }^{*}$ Lithuanian University \\ of Health Sciences, \\ Academy of Medicine}

$* *$ Hospital of Lithuanian

University of Health Sciences,

Academy of Medicine,

Clinic for Neurology
Summary. Background. In recent years, the incidence rate of multiple sclerosis (MS) has been increasing worldwide. Its heterogeneous presentation in combination with various conditions mimicking MS presents great diagnostic difficulties. Delayed treatment increases the risk of disability, therefore, establishing a clear phenotype of early MS can help in a more efficient diagnostic process. This study aimed to establish clinical features of early multiple sclerosis.

Materials and methods. A retrospective analysis of data was performed in patients hospitalized with the following ICD-10 (International Classification of Diseases Version 10) diagnoses: G37.8 (other specified demyelinating diseases of central nervous system) and G37.9 (demyelinating disease of central nervous system, unspecified). Patients hospitalized from January 1, 2015 to January 1, 2020 were included. The data was obtained from medical records and included sex, age, neurological signs and symptoms, risk factors associated with MS, and final diagnosis. Chi-squared test was used to compare categorical variables. The relationship between two quantitative variables was performed using Spearman correlation coefficient. Mann-Whitney U test and independent-samples t-test were used for comparison between groups. The results were interpreted as statistically significant when p-value $<0.05$.

Results. A total of 138 patients were included in the study: 92 (64.5\%) women and $46(35.5 \%)$ men. The patients were divided into the following age groups: 28 (20.3\%) pa-

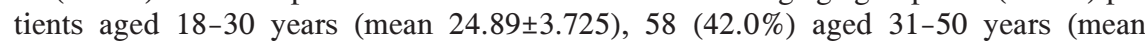
$40.43 \pm 6.093$ ), and $52(37.7 \%) 50$ years and older (mean 57.83 \pm 5.498$) .49(35.5 \%)$ patients converted to MS and $89(64.5 \%)$ patients were diagnosed with other diseases than MS. Patients converted to MS $(n=20)$ were more likely to have a diminished sense of vibration and proprioception compared with non-converted patients $(n=16),\left(\chi^{2}=9.033, p=0.003\right)$. No other differences were found between converted and non-converted patients. Converted females $(n=10)$ were more likely to have positive Rossolimo's reflex than converted males $(n=2),\left(\chi^{2}=4.451, p=0.035\right)$. Converted patients older than 50 years presented with more symptoms $(\mathrm{U}=10.519, \mathrm{p}=0.005)$ compared with younger patients and were more likely to have positive Babinski's reflex $(n=13),\left(\chi^{2}=6.993, p=0.03\right)$, decreased muscle strength $(\mathrm{n}=14),\left(\chi^{2}=13.481, \mathrm{p}=0.001\right)$, ataxia $(\mathrm{n}=13),\left(\chi^{2}=8.135, \mathrm{p}=0.017\right)$, and diminished sense of vibration and proprioception $(\mathrm{n}=12),\left(\chi^{2}=7.918, \mathrm{p}=0.019\right)$.

Conclusion. Diminished sense of vibration and proprioception was more common in MS group. Positive Rossolimo's reflex was more prevalent among converted females, whereas MS patients older than 50 years had more neurological signs and symptoms than younger patients. Positive Babinski's reflex, decreased muscle strength, ataxia, and diminished sense of vibration and proprioception were more frequent in patients older than 50 years compared with younger patients.

Keywords: multiple sclerosis, conversion, demyelination, clinical features.

\section{Address:}

\section{Ieva Čelpačenko}

Hospital of Lithuanian University of Health Sciences,

Academy of Medicine, Neurology Clinic

Eiveniu St. 2, LT-50161 Kaunas, Lithuania

E-mail: ieva.chelpachenko@gmail.com

\section{INTRODUCTION}

The incidence rate of multiple sclerosis (MS) has been increasing worldwide in recent years. An estimated 2.8 million people worldwide were living with this disease in 2020, a $30 \%$ increase compared to 2013 [1]. Similar tendencies

(C) Neurologijos seminarai, 2021. Open Access. This article is distributed under the terms of the Creative Commons Attribution 4.0 International License CC-BY 4.0 (http://creativecommons.org/licenses/by/4.0/), which permits unrestricted use, distribution, and reproduction in any medium, provided you give appropriate credit to the original author(s) and the source, provide a link to the Creative Commons license, and indicate if changes were made. 
were observed in Lithuania [2]. MS affects young people with a mean age of 32 years [1]. Moreover, women are twice more likely to be diagnosed with MS compared with men [1, 2]. Therefore, early diagnosis and treatment are key components of disease and disability prevention in young patients.

MS clinical features vary in the population, making its presentation heterogeneous. Some of the most common symptoms are motor and sensory deficits such as transient vision loss, double vision, imbalance, coordination and gait disturbances, vertigo, cranial nerves dysfunctions, loss of sphincter control, and neuralgias. Longer and more severe disease onset leads to faster disease and disability progression [3].

Different conditions such as migraine, fibromyalgia, psychogenic disorders, and neuromyelitis optica spectrum disorder can mimic MS presentation [4] making fast and accurate diagnosis a great challenge. On the average, MS is diagnosed more than a year after its first clinical manifestation [5]. Moreover, delayed treatment increases the risk of disability [6], thus establishing a clear phenotype of early MS can help in a more efficient diagnostic process.

\section{AIM}

To establish clinical features of early multiple sclerosis.

\section{MATERIALS AND METHODS}

A retrospective data analysis of patients hospitalized with ICD-10 (International Classification of Diseases Version 10) diagnoses of G37.8 (other specified demyelinating diseases of central nervous system) and G37.9 (demyelinating disease of central nervous system, unspecified) was performed. Patients hospitalized from January 1, 2015 to January 1, 2020 were included. Data were obtained from medical records and included sex, age, neurological signs and symptoms, risk factors related to MS, and final diagnosis. Approval No. BEC-MF-30 was obtained from the Bioethics Center at Lithuanian University of Health Sciences. Participants were not informed about their participation in the research as information was completely depersonalized and coded and only generalized data are published. The patients were divided into 2 groups according to the final diagnosis (MS group and non-MS group) and into 3 age groups $(18-30,30-50,>50$ years old). The prevalence and statistical difference of neurological signs and symptoms were estimated between the groups.

\section{Patient inclusion and exclusion criteria}

The included patients were adults (aged $\geq 18$ years) diagnosed with G37.8 (other specified demyelinating diseases of central nervous system) and G37.9 (demyelinating disease of central nervous system, unspecified) according to ICD-10 (International Classification of Diseases Ver- sion 10). The included patients were diagnosed between January 1, 2015 and January 1, 2020 at the Department of Neurology of Lithuanian University of Health Sciences Kaunas Clinics. Repeatedly hospitalized patients were included once if no new data were present.

\section{Statistical analysis}

All analyses were performed using SPSS (Statistical Package for the Social Sciences) version 24.0. The chi-squared test was used to compare categorical variables. The association between the two quantitative variables was performed using Spearman correlation coefficient. For comparison between groups, Mann-Whitney U test and the independent-samples t-test were used. A normal distribution was tested using Shapiro-Wilk and Kolmogorov-Smirnov tests. The results were interpreted as statistically significant when $\mathrm{p}$-value $<0.05$.

\section{RESULTS}

\section{Demographics}

A total of 138 cases were enrolled in the study: 92 (64.5\%) females and $46(35.5 \%)$ males. The age of the patients distributed into the following manner: $28(20.3 \%)$ patients

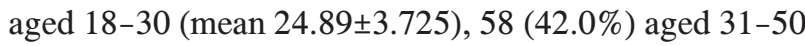
(mean $40.43 \pm 6.093$ ), and $52(37.7 \%)$ aged 50 years and older (mean 57.83 \pm 5.498$) .49(35.5 \%)$ of the enrolled patients converted to MS and $89(64.5 \%)$ were given other diagnoses than MS (either remained with the same diagnosis or were given one that is unrelated to MS). $28(57.1 \%)$ of the converted population were females and 21 (42.9\%) were males. The converted patients distributed into the following age groups: $11(22.4 \%)$ patients aged 18 to 30 years (mean age of $24.36 \pm 3.802), 19(38.8 \%$ ) patients aged 31 to 50 years (mean age $37.16 \pm 6.176)$, and $19(38.8 \%)$ patients aged 50 and more years (mean age $58.58 \pm 6.388$ ).

\section{Clinical features more common in the MS group}

Age and the sum of related neurological symptoms and signs did not differ between MS and non-MS patients. However, MS patients were more likely to have a diminished sense of vibration and proprioception $(n=20,41.7 \%)$ compared with the non-converted population $(n=16$, $18.0 \%),\left(\chi^{2}=9.033, \mathrm{p}=0.003\right)$. There were no other statistically significant differences between the groups; the results are shown in Table 1.

\section{Sex differences in the MS group}

Females diagnosed with MS were more likely to have positive Rossolimo's reflex $(\mathrm{n}=10,35.7 \%)$ compared with males $(n=2,9.5 \%),\left(\chi^{2}=4.451, p=0.035\right)$. There were no other statistically significant differences between the sexes in the MS conversion group. 
Table 1. Prevalence of clinical features in converted and non-converted population

\begin{tabular}{|c|c|c|c|c|}
\hline Variable & MS, n (\% within MS) & Non-MS, n (\% within non-MS) & $\chi^{2}$ & p \\
\hline \multicolumn{5}{|l|}{ Sex } \\
\hline Male & $21(42.9)$ & $25(28.1)$ & \multirow[t]{2}{*}{3.101} & \multirow[t]{2}{*}{0.78} \\
\hline Female & $28(57.1)$ & $64(71.9)$ & & \\
\hline \multicolumn{5}{|l|}{ Age } \\
\hline $18-30$ & $11(22.4)$ & $17(19.1)$ & \multirow[t]{3}{*}{0.390} & \multirow[t]{3}{*}{0.823} \\
\hline $31-50$ & $19(38.8)$ & $39(43.8)$ & & \\
\hline$>50$ & $33(37.1)$ & $19(38.8)$ & & \\
\hline \multicolumn{5}{|l|}{ Complaints } \\
\hline Fatigue & $4(8.2)$ & $13(14.6)$ & 1.215 & 0.27 \\
\hline Generalized weakness & $5(10.2)$ & $9(10.1)$ & 0.000 & 0.986 \\
\hline Pain & $11(22.4)$ & $32(36.0)$ & 2.687 & 0.101 \\
\hline Vertigo & $14(28.6)$ & $37(41.6)$ & 2.293 & 0.130 \\
\hline \multicolumn{5}{|l|}{ Neurological examination } \\
\hline Focal symptoms & $71(79.8)$ & $42(85.7)$ & 0.751 & 0.386 \\
\hline Cranial nerves dysfunction & $29(59.2)$ & $47(52.8)$ & 0.519 & 0.471 \\
\hline Pathological reflexes & $27(42.7)$ & $38(55.1)$ & 1.952 & 0.162 \\
\hline Babinski's reflex & $22(44.9)$ & $30(33.7)$ & 1.685 & 0.194 \\
\hline Rossolimo's reflex & $12(24.5)$ & $20(22.5)$ & 0.072 & 0.788 \\
\hline Decreased muscle strength & $21(42.9)$ & $27(30.3)$ & 2.184 & 0.139 \\
\hline Abnormal reflexes & $33(67.3)$ & $54(60.7)$ & 0.604 & 0.437 \\
\hline Muscle tone abnormalities & $8(16.3)$ & $7(7.9)$ & 2.335 & 0.126 \\
\hline Diminished sense of vibration and proprioception & $20(41.7)$ & $16(18.0)$ & 9.033 & $\mathbf{0 . 0 0 3}$ \\
\hline Diminished sense of superficial sensations & $17(35.4)$ & $30(33.7)$ & 0.040 & 0.841 \\
\hline Ataxia & $21(43.8)$ & $39(43.8)$ & 0.000 & 0.994 \\
\hline Imbalance & $21(43.8)$ & 37 (41.6) & 0.061 & 0.806 \\
\hline \multicolumn{5}{|l|}{ Urinary dysfunction } \\
\hline Urinary incontinence & $6(12.5)$ & $5(5.6)$ & 2.000 & 0.193 \\
\hline Urinary retention & $2(4.2)$ & $2(2.2)$ & 0.405 & 0.612 \\
\hline \multicolumn{5}{|l|}{ Most common risk factors } \\
\hline Thyroid disease & $1(2.0)$ & $7(7.9)$ & 1.963 & 0.259 \\
\hline Infection & $8(16.3)$ & $23(25.8)$ & 1.643 & 0.200 \\
\hline
\end{tabular}

MS - patients converted to multiple sclerosis

Non-MS - patients not converted to multiple sclerosis

Table 2. Distribution of clinical features by age (only statistically significant results)

\begin{tabular}{|c|c|c|c|c|c|}
\hline Variable & $\begin{array}{c}18-30 \text { yo, } n \\
\text { (\% within age group) }\end{array}$ & $\begin{array}{c}31-50 \text { yo, } n \\
\text { (\% within age group) }\end{array}$ & $\begin{array}{c}>50 \text { yo, } n \\
\text { (\% within age group) }\end{array}$ & $\chi^{2}$ & p \\
\hline Positive Babinski's reflex & $3(27.3)$ & $6(31.6)$ & $13(68.4)$ & 6.993 & 0.030 \\
\hline Decreased muscle strength & $1(9.1)$ & $6(31.6)$ & $14(73.7)$ & 13.481 & 0.001 \\
\hline Ataxia & $2(20)$ & $6(31.6)$ & $13(68.4)$ & 8.135 & 0.017 \\
\hline $\begin{array}{l}\text { Diminished sense of } \\
\text { vibration and proprioception }\end{array}$ & $1(9.1)$ & $7(36.8)$ & $12(63.2)$ & 7.918 & 0.019 \\
\hline
\end{tabular}

yo - years old

\section{Differences of the clinical features by age in the MS group}

MS patients older than 50 years were more likely to have positive Babinski's reflex $\left(\chi^{2}=6.993, \mathrm{p}=0.03\right)$, decreased muscle strength $\left(\chi^{2}=13.481, p=0.001\right)$, ataxia $\left(\chi^{2}=8.135\right.$, $\mathrm{p}=0.017)$, and diminished sense of vibration and proprioception $\left(\chi^{2}=7.918, p=0.019\right)$ compared with the younger patients. Results are shown in Table 2. Moreover, moderate correlation was found between age and the sum of related neurological symptoms and signs in the MS group $\left(r_{\mathrm{s}}=.419, \mathrm{p}=0.003\right)$. 


\section{Differences of the clinical features by age in the general study population}

Patients in the $>50$ years group had more symptoms in comparison with the younger patients. Mann-Whitney $\mathrm{U}$ test revealed significant differences in the sums of related neurological symptoms and signs between the groups: $18-30$ years old $($ median $=3.00,(0-6))$, $31-50$ years old (median $=5.00,(0-12))$, and older than $50($ median $=6.00,(2-13)),(\mathrm{U}=10.519, \mathrm{p}=0.005)$.

\section{DISCUSSION}

This is the first study in Lithuania aimed at determining patients' conversion from suspected demyelination to MS and clinical features that would be more common in the MS group. According to our results, $35.5 \%$ of patients converted to $\mathrm{MS}$, and diminished sense of vibration and proprioception was statistically more likely to occur in the MS group. However, different conversion rates have been shown worldwide: in Brazil it was found that $87.3 \%$ of clinically isolated syndrome (CIS) patients converted to MS during 5-year follow-up period [7], 43.9\% converted in an Indian study [8], and $85.4 \%$ in Turkey [9], respectively. However, according to the study by Liao et al, only $11 \%$ of patients with acute disseminated encephalomyelitis (ADEM) convert to MS during longer follow-up periods [10]. That said, the $35.5 \%$ rate of conversion to MS found in our study could have increased if the study had assessed a longer follow-up period.

There is conflicting evidence in the literature whether sociodemographic factors affect conversion to MS. According to some studies, an early disease onset is related to a higher risk of developing MS [8, 11-13]. However, there is evidence that age does not affect conversion to MS [7]. Likewise, our study found a low prevalence of younger patients in the MS group, however our study may be limited by the fact that only $20.3 \%$ of patients were relatively young. The risk of developing CIS is more than twice greater in females than in males, although the risk of developing MS following CIS is more evenly distributed in females having 1.2 relative risk of conversion compared to males [14]. Studies suggest that sex does not affect conversion from CIS to MS [7, 11]. Our findings seem to be consistent with the available literature.

Various clinical features have been observed to predict conversion to MS, although no consensus has been reached. It has been shown that polysymptomatic presentation can lead to a higher risk of developing MS in patients with CIS [9], but the opposite results have also been demonstrated [7]. According to our study, there was no link between the number of symptoms and conversion to MS, although older patients had more symptoms both in the general study population and in the MS conversion groups. This could mean that older patients were diagnosed with significantly progressive disease or there were other conditions mimicking MS symptoms. Moreover, sensory deficit [9], sphincter and bladder control problems [12], cerebel- lar dysfunction [7], and onset with optic neuritis [13] have been shown to predict the conversion to MS in CIS patients. Our results showed that impaired sense of vibration and proprioception was more common in the MS group. This complements previous research that idefined sensory deficit as a prognostic factor of conversion to MS.

No other studies investigating sex and age differences of the converted population have been found. Our findings show that females are more likely to have positive Rossolimo's reflex than males. Furthermore, older patients have a positive Babinski's reflex more often than younger patients. Thus, it can be assumed that females and older patients could have central motor neuron lesions more frequently. Our study was limited due to its retrospective nature, and regression models were not applicable to the data, therefore further prospective studies are needed to define a more accurate phenotype of early MS.

\section{CONCLUSION}

Diminished sense of vibration and proprioception was more common in the MS group. Positive Rossolimo's reflex was more prevalent among converted females, whereas MS patients older than 50 years had more neurological signs and symptoms than younger patients. Positive Babinski's reflex, decreased muscle strength, ataxia, diminished sense of vibration, and proprioception were more frequent in patients older than 50 years compared with younger patients.

\section{References}

1. Walton C, King R, Rechtman L, Kaye W, Leray E, Marrie RA, et al. Rising prevalence of multiple sclerosis worldwide: insights from the atlas of MS, third edition. Mult Scler J 2020; 26: 1816-21. https://doi.org/10.1177/ 1352458520970841

2. Valadkeviciene D, Kavaliunas A, Kizlaitiene R, Jocys M, Jatuzis D. Incidence rate and sex ratio in multiple sclerosis in Lithuania. Brain Behav 2019; 9(1): e01150. https://doi.org/ $10.1002 /$ brb3.1150

3. Rzepiński Ł, Zawadka-Kunikowska M, Maciejek Z, Newton JL, Zalewski P. Early clinical features, time to secondary progression, and disability milestones in Polish multiple sclerosis patients. Medicina 2019; 55(6): 232. https://doi.org/10.3390/medicina55060232

4. Solomon AJ, Bourdette DN, Cross AH, Applebee A, Skidd PM, Howard DB, et al. The contemporary spectrum of multiple sclerosis misdiagnosis. Neurology 2016; 87:1393-9. https://doi.org/10.1212/WNL. 0000000000003152

5. Ghiasian M, Faryadras M, Mansour M, Khanlarzadeh E, Mazaheri S. Assessment of delayed diagnosis and treatment in multiple sclerosis patients during 1990-2016. Acta Neurol Belg 2020; 121(1): 199-204. https://doi.org/10.1007/ s13760-020-01528-7

6. Kappos L, Freedman MS, Polman CH, Edan G, Hartung HP, Miller DH, et al. Effect of early versus delayed interferon beta- $1 \mathrm{~b}$ treatment on disability after a first clinical event sug- 
gestive of multiple sclerosis: a 3-year follow-up analysis of the BENEFIT study. Lancet 2007; 370: 389-97. https://doi.org/10.1016/S0140-6736(07)61194-5

7. Wing AC, Vasconcelos CCF, Calvet J, PapaisAlvarenga RM, Thuler LCS. Risk factors for conversion to clinically defined multiple sclerosis after clinically isolated syndrome in a racially mixed Brazilian cohort. Clin Neurol Neurosurg 2016; 146: 40-4. https://doi.org/10.1016/ j.clineuro.2016.04.022

8. Banerjee T, Saha M, Ghosh E, Hazra A, Das A, Choudhury $\mathrm{D}$, et al. Conversion of clinically isolated syndrome to multiple sclerosis: a prospective multi-center study in Eastern India. Mult Scler J Exp Transl Clin 2019; 5: 2055217319849721 . https://doi.org/10.1177/ 2055217319849721

9. Piri Çinar B, Özakbaş S. Prediction of conversion from clinically isolated syndrome to multiple sclerosis according to baseline characteristics: a prospective study. Noro Psikiyatr Ars 2018; 55(1): 15-21.

10. Liao MF, Huang CC, Lyu RK, Chen CM, Chang HS, Chu CC, et al. Acute disseminated encephalomyelitis that meets modified McDonald criteria for dissemination in space is associated with a high probability of conversion to multiple sclerosis in Taiwanese patients. Eur J Neurol 2011; 18: 252-9. https://doi.org/10.1111/j.1468-1331. 2010.03114.x

11. Tintore M, Rovira À, Río J, Otero-Romero S, Arrambide G, Tur C, et al. Defining high, medium and low impact prognostic factors for developing multiple sclerosis. Brain 2015; 138: 1863-74. https://doi.org/10.1093/brain/awv105

12. Ruet A, Deloire MS, Ouallet JC, Molinier S, Brochet B. Predictive factors for multiple sclerosis in patients with clinically isolated spinal cord syndrome. Mult Scler J 2011; 17: 312-8. https://doi.org/10.1177/1352458510386999

13. Ferraro D, Simone AM, Bedin R, Galli V, Vitetta F, Federzoni L, et al. Cerebrospinal fluid oligoclonal IgM bands predict early conversion to clinically definite multiple sclerosis in patients with clinically isolated syndrome. J Neuroimmunol 2013; 257: 76-81. https://doi.org/10.1016/ j.jneuroim.2013.01.011

14. Dobson R, Ramagopalan S, Giovannoni G. The effect of gender in clinically isolated syndrome (CIS): a meta-analysis. Mult Scler J 2012; 18: 600-4. https://doi.org/10.1177/ 1352458511426740

\section{I. Čelpačenko, R. Stankevičiūtė, M. Malciūtė, R. Balnytė ANKSTYVOS IŠSĖTINĖS SKLEROZĖS KLINIKINIAI POŽYMIAI}

\section{Santrauka}

Ivadas. Pastaraisiais metais visame pasaulyje stebimas didejantis išsėtinės sklerozės (IS) paplitimas. IS pasižymi heterogeniška klinika, taip pat IS būdingi simptomai gali pasireikšti sergant ivairiomis kitomis ligomis, kas neretai apsunkina IS diagnostiką. Vèlesnè ligos diagnozė yra siejama su didesne negalios rizika, todèl aiškus ankstyvos IS fenotipas galètų padèti vykdyti sklandesnị ligos diagnozavimo procesą. Šio tyrimo tikslas buvo nustatyti ankstyvos IS klinikinius bruožus.

Tiriamieji ir tyrimo metodai. Buvo atlikta retrospektyvinė duomenu analizè, tiriant pacientus, hospitalizuotus su šiomis TLK-10 (Tarptautinè ligų klasifikacija) diagnozėmis: G37.8 (kitos patikslintos demielinizuojančios nervų sistemos ligos) ir G37.9 (demielinizuojančios centrinès nervų sistemos ligos, nepatikslintos). Duomenys buvo rinkti nuo $2015 \mathrm{~m}$. sausio $1 \mathrm{~d}$. iki 2020 m. sausio 1 d., įtraukiant lytị, amžių, nusiskundimus, neurologinio ištyrimo duomenis, su IS susijusius rizikos veiksnius ir galutinę diagnozę. Statistinè analizè atlikta naudojant SPSS (Statistical Package for the Social Sciences) 24.0 versiją. Chi kvadrato testas naudotas kategoriniams kintamiesiems palyginti, asociacija tarp dviejų kiekybinių kintamųjų apskaičiuota naudojant Spirmeno koreliacijos koeficientą. Dviejų grupių palyginimams naudota Mano-Vitnio U testas bei nepriklausomy imčių t-testas. Rezultatai laikomi statistiškai reikšmingais, kai $\mathrm{p}<0,05$.

Rezultatai. İ tyrimą buvo įtraukti 138 pacientai: 92 (64,5\%) moterys ir $46(35,5 \%)$ vyrai. Pagal amžių pacientai suskirstyti i grupes: $28(20,3 \%)$ pacientai 18-30 metu amžiaus (vid. $24,89 \pm 3,725), 58(42,0 \%)-31-50$ metų amžiaus (vid. $40,43 \pm 6,093), 52(37,7 \%)-50$ metu ir vyresni (vid. $57,83 \pm 5,498) .49(35,5 \%)$ pacientams buvo nustatyta IS, $89(64,5 \%)$ - kitokios diagnozès. Konvertavusiems ị IS ( $n=20)$ dažniau pasireiškè sutrikę gilieji jutimai nei nekonvertavusiems pacientams $(n=16),\left(\chi^{2}=9,033, p=0,003\right)$. Daugiau statistiškai reikšmingų skirtumų tarp grupių nebuvo nustatyta. Tarp pacientų, kuriems nustatyta IS, moterims $(\mathrm{n}=10)$ dažniau buvo nustatytas patologinis Rosolimo refleksas, lyginant su vyrais $(\mathrm{n}=2),\left(\chi^{2}=4,451, \mathrm{p}=0,035\right)$. Vyresniems nei 50 metų IS pacientams nustatyta daugiau simptomų nei jaunesniems pacientams $(\mathrm{U}=10,519, \mathrm{p}=0,005)$. Dažniau buvo nustatyta nusilpusi raumenu jèga $\left(\chi^{2}=13,481, \mathrm{p}=0,001, \mathrm{n}=14\right)$, patologinis Babinskio refleksas $\left(\chi^{2}=6,993, \mathrm{p}=0,03, \mathrm{n}=13\right)$, ataksija $\left(\chi^{2}=8,135, \mathrm{p}=0,017, \mathrm{n}=13\right)$, sutrikę gilieji jutimai $\left(\chi^{2}=7,918\right.$, $\mathrm{p}=0,019, \mathrm{n}=12)$, lyginant su jaunesniais į IS konvertavusiais pacientais.

Išvados. Giliuju jutimų sutrikimas yra labiau paplitęs tarp pacientų, kuriems buvo nustatyta IS. Patologinis Rosolimo refleksas yra dažnesnis tarp ị IS konvertavusių moterų nei tarp vyrų, o vyresni nei 50 metų IS sirgę pacientai turejo daugiau simptomų, tarp kurių buvo patologinis Babinskio refleksas, nusilpusi raumenų jèga, ataksija ir sutrikę gilieji jutimai.

Raktažodžiai: išsètinè sklerozè, konversija, demielinizacija, klinikiniai bruožai.

Gauta:

20210414

Priimta spaudai: 20210511 